\title{
THE IMPACT OF FOREIGNERS' TRADES ON EQUITY PRICES: EVIDENCE FROM MACEDONIAN STOCK EXCHANGE
}

Julijana Angelovska

\begin{abstract}
Emerging countries' economies are dependent on foreign capital inflows. For policy makers and researchers of particular interest is to understand the nature of these flows and their impact on the domestic capital market. The first significant foreign inflows entered the Macedonian Stock Market at the end of 2004, and stock prices were increased. It was general belief among the investors that foreigners are driving the prices on the Macedonian Stock Market. This study examines the influence of foreign investors' trades on stock returns in Macedonia using base broadening and price pressure hypotheses. Strong evidence consistent with the base-broadening hypothesis shows that $1 \%$ of monthly net inflows as a percentage of last month market capitalization is connected with $7 \%$ rise in monthly returns on the Macedonian stock market. The findings do not support the price pressure hypothesis, so the rise in the prices is permanent.
\end{abstract}

Key words: foreign investor, price pressure, base broadening, equity price, Macedonian Stock Market.

JEL Classification: F32, G14, 016

\section{INTRODUCTION}

Emerging stock markets in Balkans are generally small and illiquid. Thus, extreme price volatility is a matter of concern for investors and policy makers alike as guest in trading activities can exert significant pressure on prices. It comes as no surprise that regulators of these markets closely monitor the movement of foreign equity flows into their markets, and this movement has increased tremendously over the last two decades following a general trend in market liberalization (Pavabutr and Yan 2007). Even though there is an evidence that liberalization in these markets attracts more foreign portfolio investments and leads to both improvement in market liquidity and reduction in the cost of capital (Bekaert and Harvey 2000; Henry 2000), there is a lingering concern that the mobility of foreign equity flows may cause extreme volatility in these fragile markets. Macedonia, as small emerging country in the process of transition is dependent on international portfolio capital inflows. Opposite to direct investments, foreign inflows in capital market is associated with sudden increase in the stock prices when they enter the market and opposite sudden decrease in stock prices when they exit the market. Policy makers and researchers have been interested

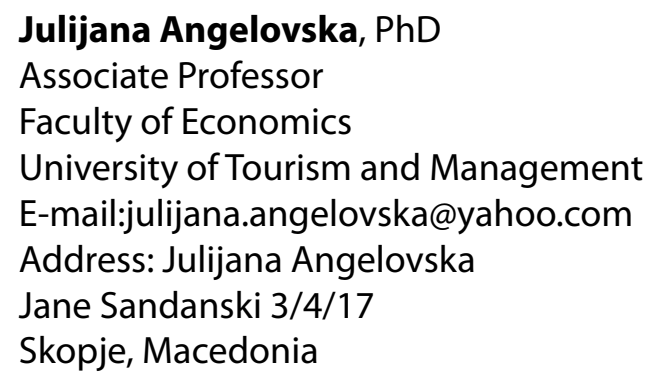


in understanding this nature of those flows and their impact on domestic financial markets (Pavabutr and Yan 2007; Bekaert and Harvey 2000; Henry 2000). Arguments that Capital flow liberalization of Foreign Portfolio Investment will increase the liquidity and the efficiency of local markets are used by defenders of these trends. It is supported by the fact that in the long run, as a result of market integration the expected returns will decrease. The studies of Henry (2000), Bekaert and Harvey (2002), and Kim and Singal (2000) address this issue and test the abnormal returns after market liberalization and argue that, start-up companies as well increases the liquidity of local markets, and makes the base of investor broader, increasing the risk sharing if more foreign investors enter these emerging markets.

As in other emerging stock markets the Macedonian Stock Exchange (MSE), foreign investors' transactions are recorded and made public on a monthly basis since 2005 . The record of investors' transactions data provides opportunity to researchers to analyze the trading patterns of foreign investors'; to find out the impact of their trades on stock returns, and the information contained in their trades.

The purpose of this research is to examine the effects of foreigners' inflow on stock prices at the Macedonian Stock Market. To investigate if the rise of stock prices at the Macedonian Stock Exchange is result of broadening of the base of investors "Base broadening" hypothesis is used.

To investigate if the increase of the prices at the Macedonian stock market is temporary or permanent, price pressure hypothesis is used.

The study will add value to the literature that investigates the impact of foreign investors' trade on the stock market movements in emerging countries. To our knowledge till now such research about the influence of foreign' inflows on the Macedonian Stock Exchange has not been done. It is of great importance for policy makers and participants on the Macedonian Stock Market the behavior and effects of foreign flows to the stock market. The research will contribute to the scarce literature on this topic in emerging Balkan countries.

The remainder of the article is organized as follows. Section 1 discusses the literature on the effects of foreigners' inflow on the stock prices. Section 2 describes the development of the Macedonian Stock exchange. Section 3 describes dataset and the methodology on base broadening and price pressure hypothesis. Section 4 presents the empirical findings, and the conclusion evaluates whether the results warrant any change in the hither to conventional conclusion.

\section{LITERATURE REVIEW}

The informational and allocation role of asset markets can be enhanced by speculative activity and make markets more efficient as economic theory generally suggests (Grossman 1995; Grossman and Stiglitz 1980). The role of foreign speculative activity in emerging markets is found to be of a particularly importance.

The researchers have been investigating the joint dynamics of foreign investor flows in equity markets and equity returns. Foreigners' trades have been closely watched by local market participants and have strong influence on equity prices, and their trading. The researches associated with foreign trading in the emerging markets are with particular focus on the effect of foreign trading flows on returns. Tesar and Werner (1995a, b), Bohn and Tesar (1996), and Brennan and Cao (1997), Choe at al. (1999) found positive, contemporaneous correlations between international portfolio inflows and stock returns in emerging markets. The increase in the share prices caused by an increase in the foreign participation can be explained by two main factors based on the market segmentation theories. One factor can be indentified in increasing the investor base by foreign investments' inflows. Increased investor base enables diversification and risk sharing increases, thus lowering the risk premium of stocks (Merton 1987; Errunza and Losq 1989) and second factor is that flow of new investors can influence liquidity risk to be lower. Market segmentation model offered by Merton (1987) shows that a wider investor base for a given stock can result in equity prices rise. The application of this model is suitable for the emerging market case, because it can illustrate how the inclusion of foreign investors and broadened investor base will affect the prices. The model was used by Clark and Berko (1996) to show the impact of foreign portfolio investment in Mexico and they presented graphically that during the period analyzed the percentage of foreign investor holdings in Mexico had increased. Formal statistical test must be included to show its significance that investor base is really broadening. In this line tests for co-integration of Brazilian stock returns and FEPI on the São Paulo Stock Exchange (Bovespa) was done (Tabak 2003). Cointegration of order one was found between Bovespa index and the FEPI (Tabak 2003) and an error correction model was built, being the FEPI series integrated of order one during the period analyzed. Brennan and Cao (1997) argued that the contemporaneous correlations may be attributed to international investors updating their forecasts more frequently than local investors in response to the public release of market 
information. Yu and Lai (1999) and Lin and Ma (2002) also found that trades by foreign investors influence the Taiwanese stock market. In a segmented market case with foreign investors, the return is the product of the world market beta and the world risk premium (Bekaert and Harvey 2002). Therefore, in a segmented market, it is expected to have lower returns. Security prices may substantially and persistently move away from fundamentals, which base their transactions on strategies far from the fundamental values of investments (Angelidis, Koulakiotis and Kiohos 2018). The results are in line with the equity market segmentation theory (Stulz 1995) which explains that increase in the investor base in emerging stock markets will increase risk sharing and liquidity, consequently expected returns will fall and prices will rise.

The second factor that can explain the contemporaneous relationship between foreign investment flows and security returns is the price pressure hypothesis. This hypothesis assumes that due to low liquidity of emerging markets, very high trading volumes of foreign investors for the size of these markets will cause price pressures. Using Warther (1995) approach Clark and Berko (1996) investigated price pressure by foreign investors in the Mexican stock market. The results of their analysis are quantified: unexpected net foreign flows as the sum of $1 \%$ of the market capitalization is associated with an increase in prices by about $8 \%$. The results did not reveal shifts in prices in favor of the hypothesis of pressure on prices in the Mexican market (Clark and Berko 1996). Also Dahlquist and Robertsson (2004) studying the investment behavior and the influence of foreign investors on the Swedish capital market, using monthly data documented that net foreign flows equal to $1 \%$ of the market capitalization is associated with a $2.7 \%$ increase in prices and would pressure prices. Richards (2005), using daily data from six Asian developing countries revealed that net foreign purchases equal to $1 \%$ of the market capitalization is associated with a $38 \%$ cumulative increase in prices, while İkizlerli and Ülkü (2008) using monthly data estimated that net foreign purchases of equal $1 \%$ of the market capitalization on the Istanbul Stock Exchange is related to $14.89 \%$ increase in stock prices and also revealed no pressure on prices. No evidence of price pressure on institutional equity flows is found also by Froot and Ramadorai (2001).

The behavior and the impact of foreign investors' inflows on stock prices have been investigated in the literature in two main points. Focus in the first is on granger causality or concurrent movement between foreign flows and stock's returns. The second one focuses on positive feedback trading, herding, volatility jumps and price pressure to detect anomalies that may cause destabilizing effects of foreign investments on stock prices. There are researches that are using theoretical models based on information asymmetries between local and foreign investors and assumed that the local investors would have an information advantage that would impact prices. That information advantage of local investors will push price movements that will be a signal to foreigners, leading to positive feedback trading by this type of investors. Brennan and Cao (1997) found that there is a contemporaneous relationship between foreign portfolio flows and local market returns. Using quarterly data of US investments in foreign equity markets (developed and emerging) found a positive contemporaneous correlation of these flows and local stock market returns in most of the countries under the empirical research (Bohn and Tesar 1996; Brennan and Cao 1997).

\section{SOME STYLIZED FACTS ABOUT MACEDONIAN CAPITAL MARKET}

The structural changes in the Republic of Macedonia during 1990s, crossing the country's transition to free market economy enabled development of the Macedonian capital market. The formation of joint stock companies during the process of privatization imposed the necessity of creating the market infrastructure for the transfer of newly created securities (Angelovska 2014). The constitution of the Macedonian Stock Exchange was in September 1995, and was lagging behind many regional stock markets passing through the same transition period that were established earlier. The stock market in Macedonia grew gradually, along with economic development and intensification of reforms in the years that followed (Table 1).

A robust development of the Macedonian Stock Market has been noticed since 2005 (Angelovska 2014). Turbulent period in the following years is associated with first bull and first bear market in the short history of the Macedonian Stock Exchange. The investors in securities have experienced either extreme capital gains (2005-2007) or extreme capital losses (2008-2009). The movement of the MBI 10 index in the period 2005-2015 is shown in Figure 1, and gives explanation why under investigation in this study is the turbulent period 2005-2009. It can be seen that the peak was reached at the end of August 2007 index reaching 10057.77 (the $\mathrm{MBI}$ started in 2005 with index value of 1000). The 'bear market' happened in 2008 and 2009 with the market loses of almost $80 \%$. At the end of 2008 the index was 2096.16 losing $80 \%$ of his value, and continue till March 2009 when the index 
Table 1. Macedonian Stock Market in the period 1996-2008 (mil. EUR)

\begin{tabular}{|c|c|c|c|c|c|}
\hline & GDP & $\begin{array}{l}\text { Trading } \\
\text { Volume* }^{*}\end{array}$ & $\begin{array}{l}\text { Trading volume (block } \\
\text { transaction excluded) }\end{array}$ & $\begin{array}{c}\text { Market } \\
\text { capitalization* }\end{array}$ & $\begin{array}{l}\text { Market capitalization/ } \\
\text { GDP x100 }\end{array}$ \\
\hline 1996 & 3319 & 0.65 & 0.67 & & \\
\hline 1997 & 3241 & 19.2 & 19.58 & & \\
\hline 1998 & 3150 & 76.97 & 10.46 & & \\
\hline 1999 & 3448 & 25.61 & 5.25 & & \\
\hline 2000 & 3893 & 128.12 & 19.1 & & \\
\hline 2001 & 3839 & 472.83 & 19.1 & & \\
\hline 2002 & 4001 & 94.19 & 31 & 523 & 13.08 \\
\hline 2003 & 4105 & 123.41 & 37.7 & 638 & 15.54 \\
\hline 2004 & 4325 & 135.57 & 44.8 & 889 & 20.56 \\
\hline 2005 & 4676 & 145.02 & 116.5 & 1218 & 26.04 \\
\hline 2006 & 5176 & 506.91 & 176.6 & 1780 & 34.39 \\
\hline 2007 & 5791 & 681.63 & 498.5 & 5052 & 87.23 \\
\hline 2008 & 6509 & 202.04 & 132.7 & 2032 & 32.32 \\
\hline
\end{tabular}

Note: *Official and regular market ** total market capitalization (shares and bonds).

Source: Eurostat, Macedonian Stock Exchange.

fall to 1598.50 and finished the year with 2751.88. The graph shows the volatility at the Macedonian Stock Exchange that is mostly pronounced in the period of investigation. The investors in Macedonia and other transition countries that moved in a similar way learned the behavior of the stock market in a very expensive way.
In the period that follows 2009, Macedonian index $\mathrm{MBI} 10$ is characterized by stable downsizing line starting in 2010 with maximum value of 2978.26 (4th February), to minimum at $8^{\text {th }}$ of November 2013 (1556.96). This period is associated with low liquidity and even if the foreigners wanted to exit the market it was difficult due to the low trading volume or lack of investors' interest to buy stocks.

Figure 1. MBI performances during the period 2005-2015

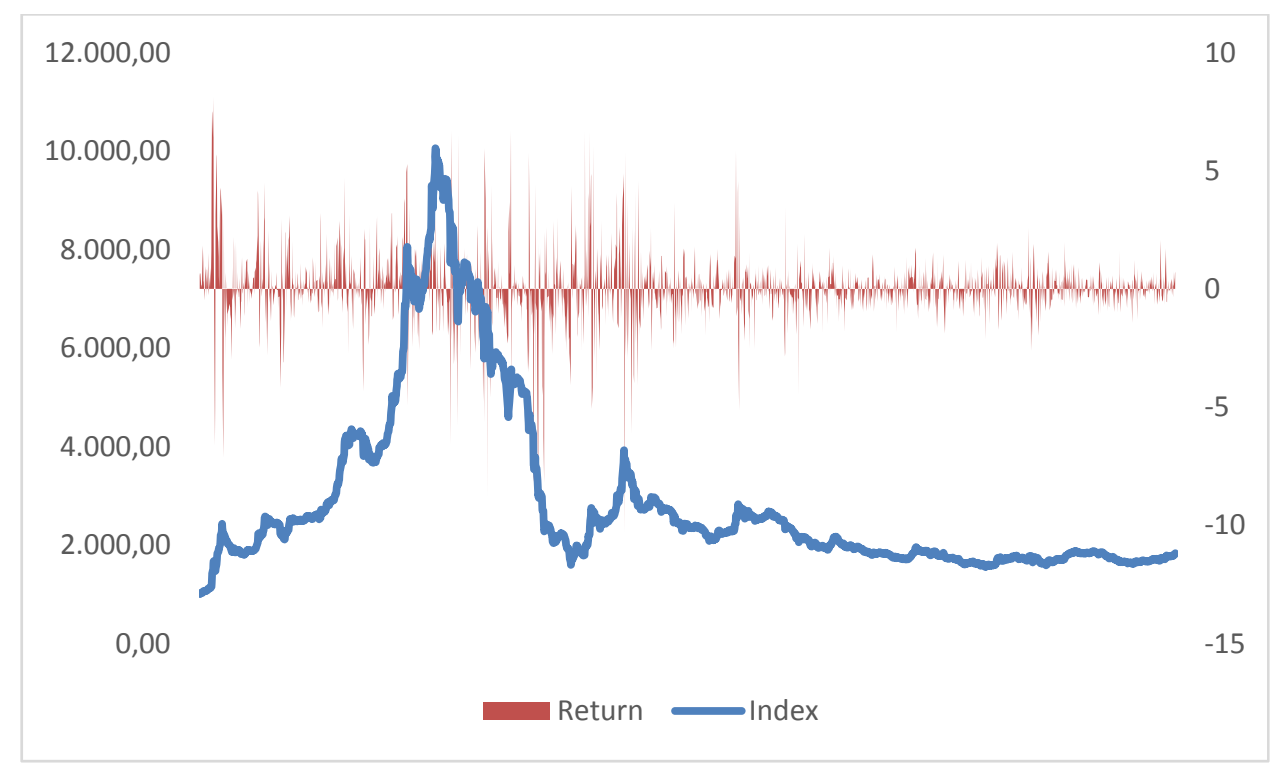

Source: MSE 


\section{DATA AND METHODOLOGY}

\subsection{Methodology on Foreign Portfolio Flows 3.1.1 Base Broadening}

Market segmentation model (Merton 1987) postulates that the equity prices rise for a given stock may be caused as a result of a wider investor base. The model can be used to illustrate how the prices will be affected when foreign investors is broadened the investor base in the emerging stock markets. To assess the impact of foreign portfolio investment in Mexico Clark and Berko (1996) used this model.

$$
\mathrm{R}_{\mathrm{t}}=\beta_{0}+\beta_{1} \frac{\mathrm{N}_{\mathrm{t}}}{\mathrm{MCap}_{\mathrm{t}-1}}
$$

Rt return

$\mathrm{Nt}$ net foreign inflow

MCap $_{\mathrm{t}-1}$ market capitalization, at time t-1

$$
\mathrm{H}_{0}: \beta_{1}=0 \mathrm{H}_{1}: \beta_{1}>0
$$

If base-broadening hypothesis holds expectation is to reject the null hypothesis.

\subsubsection{Price pressure}

The contemporaneous relationship between foreign flows and local stock returns can also be explained with the price pressure meaning that trading volumes of foreign investors are very high for the size of emerging markets and may cause price pressures due to low liquidity of the emerging markets. Adapted Warther (1995) approach was used by Clark and Berko
(1996) to investigate foreign inflows impact on the stock market prices in Mexico. In the model returns as dependent variable are regressed with net foreign inflows and unexpected inflows lagged for 3 months.

$$
\mathrm{R}_{\mathrm{t}}=\beta_{0}+\sum_{\mathrm{i}=1}^{4} \beta_{\mathrm{i}} \mathrm{U}_{\mathrm{t}+1-\mathrm{i}}\left(\frac{\mathrm{N}_{\mathrm{t}}}{\mathrm{MCap}_{\mathrm{t}-1}}\right)
$$

Rt return

$\mathrm{Nt} \quad$ net foreign inflow

$\mathrm{MCap}_{\mathrm{t}-1}$ market capitalization, at time $\mathrm{t}-1$

$\mathrm{U}_{\mathrm{t}+1} \quad$ unexpected inflows

$$
H_{0}: \beta_{1}, \beta_{2}=0 H_{1}: \beta_{1}, \beta_{2}<0
$$

The coefficients of lagged unexpected flows would be negative and significant if the price pressure hypothesis holds.

\subsection{Data}

Data used in this study are monthly based, during the period from January 2005 to December 2009. The data are obtained directly from Macedonian Stock Exchange and Macedonian Central Securities Depository, which includes monthly gross purchases and sales by foreign investors for all firms included in MBI 10 index, since January 2005.

MBI10 stock index is used as a market return and is computed by taking the first difference of the logged monthly closing values of the MBI10 index in local currency.

Figure 2 shows percentage of participation of foreign investors in the listed company's total equity and

Figure 2. Participation of foreign investors in the listed company's equity (right axis) and monthly movement of the index MBI10 in the period 2005-2009 (left axis).

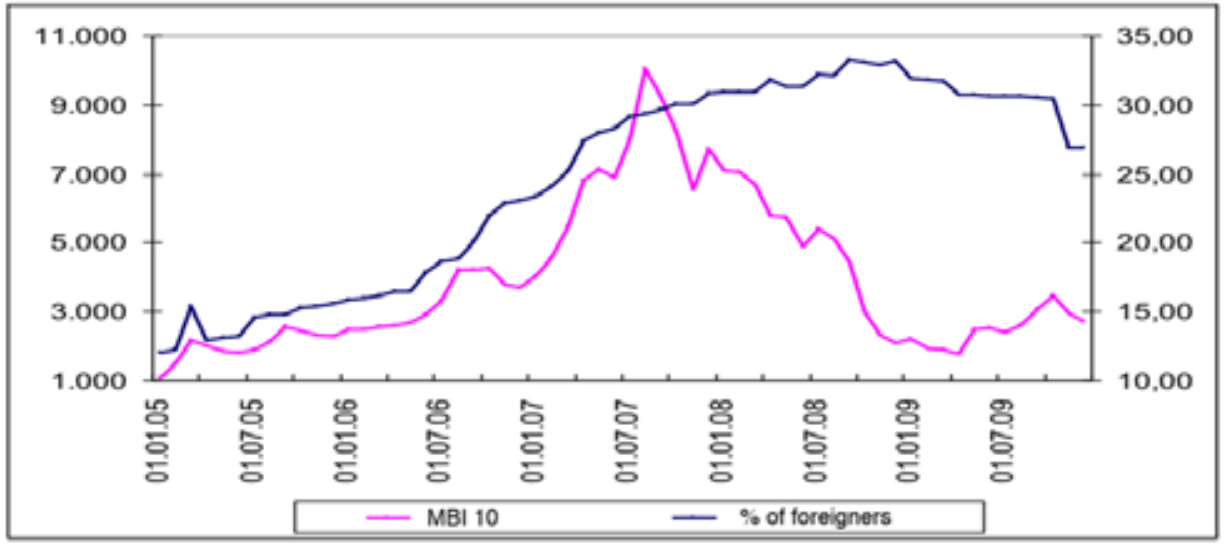

Source: MSE and Central Securities Depository 
Figure 3. Participation of foreign investors in the listed company's equity (right axis) and monthly movement of their share prices in the period 2005-2009 (left axis)
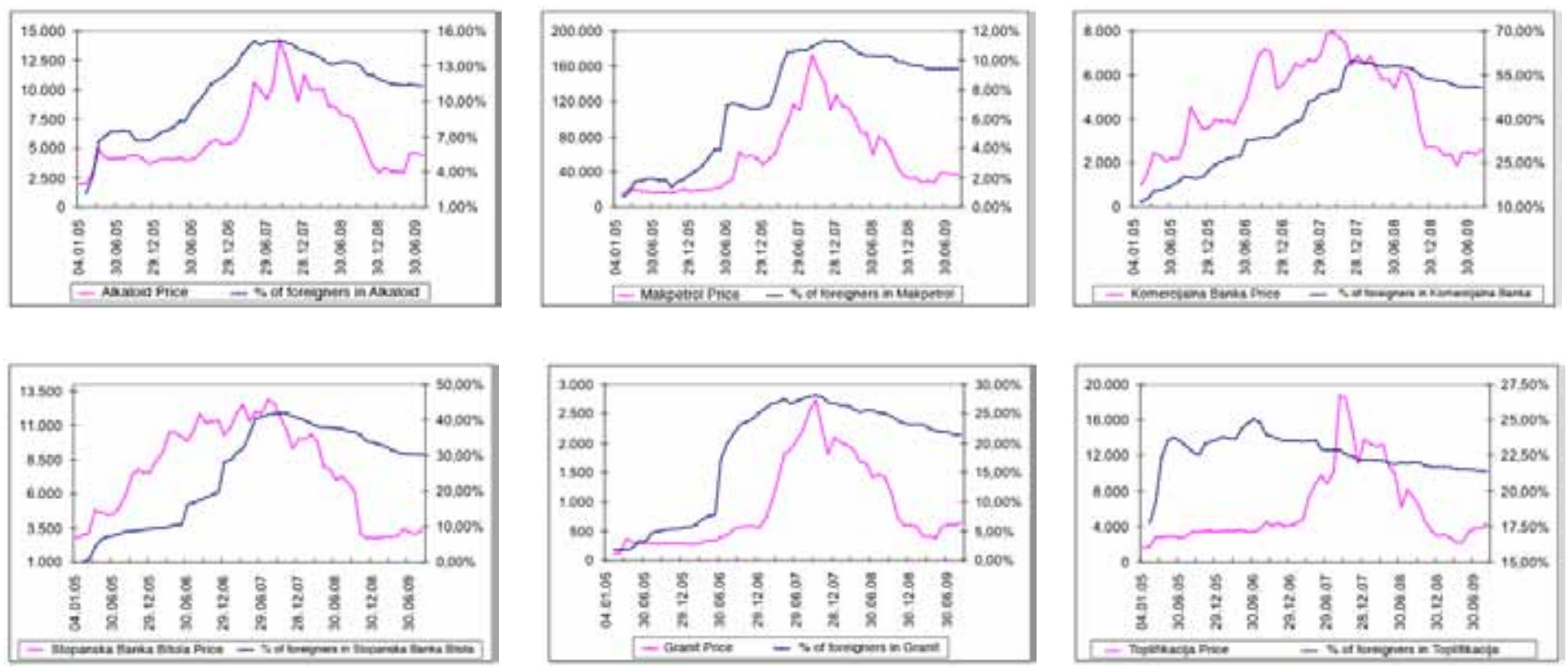

Source: MSE

monthly movement of the index MBI10 in the period 2005-2009. The percentage of foreign participation in companies equity included in MBI 10 index during the observed period has mean value of $24.6 \%$ with standard deviation, $7.3 \%$, minimum value of $12.04 \%$ and maximum value of $33.33 \%$.

The participation of foreign investors in the equity of the companies: Alkaloid, Makpetrol, Granit, Toplifikacija, Stopanska Banka Bitola and Komercijalna Banka Skopje are shown in Figure 3 together with monthly movement of the particular company's share prices. Similar movement of the participation of foreigners in the company's equity and rise of the stock price can be noticed.

Table 2 shows the summary data on sales for all firms of MBI 10 and foreigners' aggregated purchases. In the first 3 years net purchases were positive and the maximum was reached in 2007. After 2007, they began to decrease and net inflows made by foreigners became negative.

Figure 4 shows time trend of monthly buying and selling of foreigners as a percentage of total trading volume, where obviously is shown that when foreigners are buyers stock prices rise, or during the boom 2005-2007, on the Macedonian Stock Exchange, and when they started to sell the market went down, 2008-2009.

The "net purchase" and "net inflow" are used interchangeably as a measure of purchases minus sales by foreigners on the MSE. If the variables such as sales, purchases, and net purchases are not stationary variables, there is need for normalization (Bekaert et al. 2002; Dahlquist and Robertson 2004; Griffin et al. 2004 and Richards 2005). Normalization of the variable net

Table 2. Summary statistics

\begin{tabular}{|l|c|r|r|r|r|}
\hline & 2005 & 2006 & 2007 & 2008 & 2009 \\
\hline $\begin{array}{l}\text { Market capitalization- shares in } \\
\text { billion denars }\end{array}$ & 50.66 & 86.48 & 288.77 & 106.29 & 122.08 \\
\hline MBI Return-yearly & 129.2 & 61.54 & 109.07 & -72.92 & 31.28 \\
\hline Sales - foreigners & 0.64 & 1.28 & 7.38 & 5.61 & 3.53 \\
\hline Purchase -foreigners & 2.76 & 5.64 & 18.80 & 3.86 & 2.91 \\
\hline Net-buying-foreigners & 2.12 & 4.36 & 12.22 & -1.52 & -0.62 \\
\hline Volatility: Net-buying-foreign & 0.14 & 0.20 & 0.89 & 0.22 & 0.05 \\
\hline
\end{tabular}

Source: MSE and Central Securities Depository 
Figure 4. Time trend of monthly buying and selling by foreigners as a $\%$ of total market volume

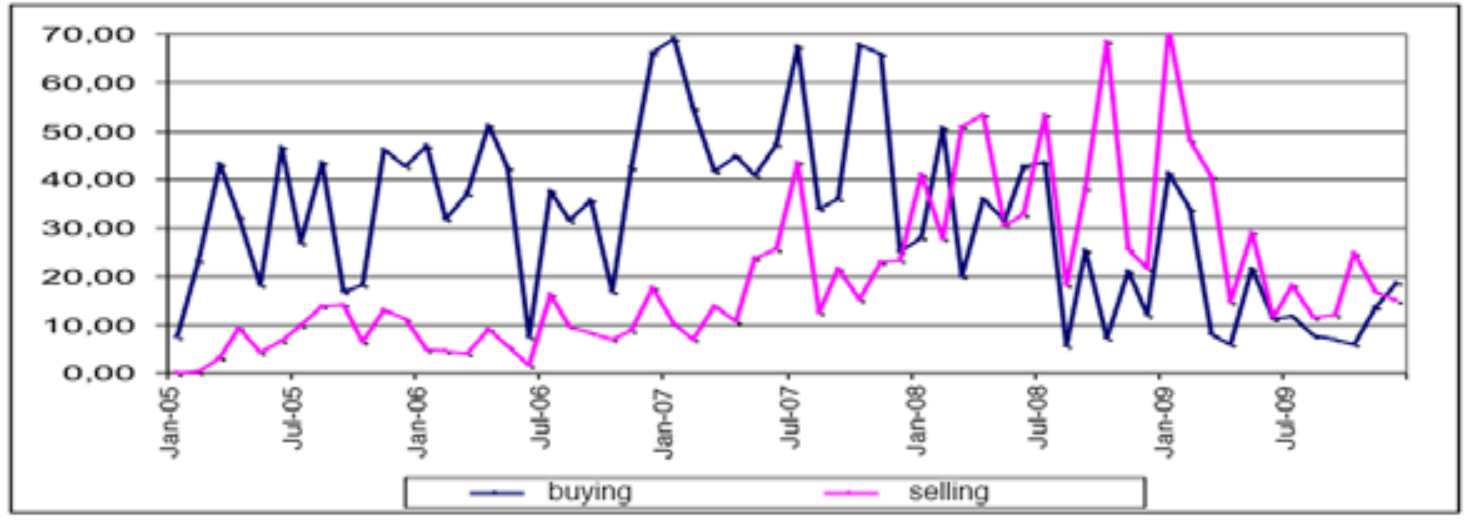

Source: MSE and Central Securities Depository

Figure 5. Monthly Net inflows of foreigners as a percentage of market capitalization.

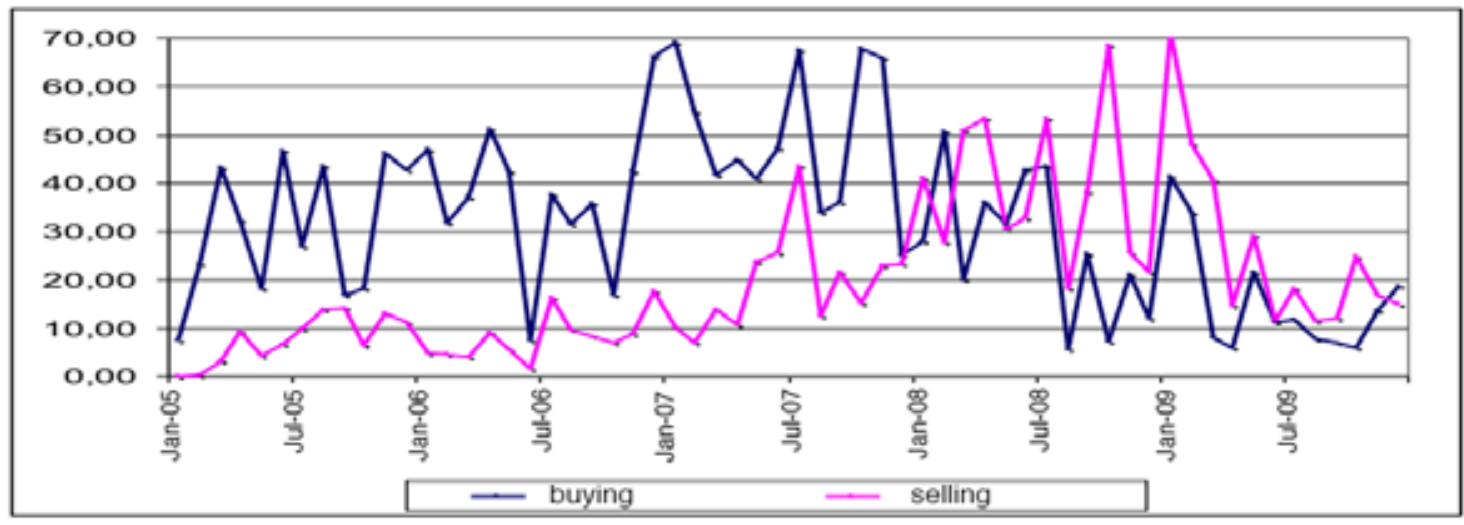

Source: MSE and Central Securities Depository

purchases can be done by dividing it by the contemporaneous market capitalization. Such normalization is done and it is useful to figure out how important the net demand is compared to total supply of available shares. Figure 5 shows normalized variable - Net purchases of foreigners as a percentage of total market capitalization throughout the sample period.

Monthly Net inflows of foreigners as a percentage of market capitalization in the period of January 2005 to December 2009 were mostly positive with mean of $0.25 \%$, but the volatility measured in standard deviation was significant with mean of 0.36 or maximum percentage was $1.2 \%$ and minimum $-0.48 \%$ participation in market capitalization. In the period of boom 2005-2007 mean was $0.46 \%$, with maximum $1.2 \%$ and minimum $0.001 \%$, and standard deviation of 0.31 , and in the recession period 2008-2009, the mean was negative $-0.07 \%$.

\section{RESULTS}

\subsection{Preliminary Analysis: Stationarity and Autocorrelation}

To find properties of the time series a formal statistical test is necessary. Therefore, ADF (Augmented Dickey and Fuller) is used to test the stationarity of the foreigner's net inflows, net inflows as a percentage of market capitalization, monthly indices and monthly returns. The results in Table 3 strongly suggest that the net inflows as \% of market capitalization is stationary, i.e., integrated of order zero I(0). The monthly returns are stationary, i.e., $\mathrm{I}(0)$.

The second step is to test for autocorrelation whish can reveal a lot about the predictability of the variables. The variable net inflow is transformed as a percentage of last month market capitalization as suggested in Richards (2005). Tests are shown in Table 4 and can be noticed bigger autocorrelation in 
Table 3. ADF test statistics

\begin{tabular}{|c|c|c|c|c|}
\hline & Net inflows & $\begin{array}{c}\text { Net inflows as \% of } \\
\text { market capitalization }\end{array}$ & Monthly indices & Monthly returns \\
\hline ADF test -statistics & -4.207790 & -3.481245 & -1.460737 & -5.468365 \\
\hline
\end{tabular}

MacKinnon critical values to reject the hypothesis for unit root: $1 \%$ level of significance $-3.436749,5 \%$ level of significance $-2.864254,10 \%$ level of significance -2.568267 .

Table 4. Autocorrelation and Q-statistics

\begin{tabular}{|c|c|c|c|c|}
\hline & ACF net inflows & Q-statistics & ACF returns & Q-statistics \\
\hline 1 & 0.607 & 22.828 & 0.307 & 5.8269 \\
\hline 2 & 0.407 & 33.296 & 0.028 & 5.9761 \\
\hline 3 & 0.380 & 42.583 & -0.107 & 7.4526 \\
\hline 4 & 0.301 & 51.710 & 0.105 & 8.9139 \\
\hline 5 & 0.220 & 56.283 & 0.147 & 10.058 \\
\hline
\end{tabular}

net inflows as percentage of last month market capitalization than in the returns, so positive autocorrelation can mean that increase in net foreign inflow will be followed by farther inflows in the next months. Q-statistics is calculated to provide more evidence of autocorrelation in the monthly series.

\subsection{Results: Base broadening hypothesis}

Hypothesis for base broadening says that with foreign investors' inflows the base of investors on the local market is increased and will cause the rise in prices. The results of regression in equitation (1) are shown in Table 5.

The statistically significant positive coefficient in base broadening hypothesis shows that the null can

Table 5. Regression results from Equation (1)

\begin{tabular}{|c|c|c|c|}
\hline $\begin{array}{c}\text { Dependent } \\
\text { variable }\end{array}$ & Coefficient & t-statistics & Probability \\
\hline C & -0.44 & -0.19 & 0.84 \\
\hline $\begin{array}{c}\text { \% Net inflows in } \\
\text { MC(-1) }\end{array}$ & 6.99 & 2.63 & 0.01 \\
\hline
\end{tabular}

be rejected, and the conclusion is that there is base broadening. $1 \%$ of monthly net inflows as a percentage of last month market capitalization are connected with $7 \%$ rise in monthly returns on the Macedonian stock market.

\subsection{Unexpected net foreign inflows as a percentage of market capitalization}

Even if there is evidence in favor of base broadening hypothesis the coefficient $\beta_{1}$ from Table 5 would likely understate the impact of foreign inflows on the Macedonian capital market. The efficient market hypothesis implies that relevant information available at the start of the period should rise ahead of the actual inflows. So the expectation that foreign demand ultimately would raise the prices up, even if they invest gradually, prices should rise ahead of the actual inflows. Moreover if the investors are unsure about the magnitude of new foreign demand for Macedonian stocks and the arrival of the information will causes investors to raise their estimate of total foreign inflows that should push the prices to higher level. Expectation on the stock market is of great importance and taking into consideration this,

Table 6. Regression coefficients on net foreign inflows as a percentage of market capitalization (A3)

\begin{tabular}{|c|c|c|c|c|}
\hline & Coefficient & St. error & t-statistics & Probability \\
\hline C & 0.33 & 0.27 & 1.24 & 0.22 \\
\hline AR(1) & 0.61 & 0.11 & 5.67 & 0.00 \\
\hline$A R(2)$ & -0.04 & 0.11 & -0.39 & 0.69 \\
\hline AR(3) & 0.19 & 0.07 & 2.84 & 0.01 \\
\hline$R^{2}$ & 0.48 & \multicolumn{2}{|c|}{ Akaike } & 1.58 \\
\hline Durbin-Watson & 2.02 & Schwarz & 1.73 \\
\hline
\end{tabular}


Table 7. Regression results from Equation (2)

\begin{tabular}{|l|c|c|c|c|}
\hline Dependent variable & Coefficient & St. error & t-statistics & Probability \\
\hline C & 1.60 & 1.88 & 0.85 & 0.40 \\
\hline Unexpected inflows & 0.29 & 3.73 & 0.08 & 0.94 \\
\hline Unexpected inflows (-1) & 1.47 & 3.73 & 0.40 & 0.69 \\
\hline Unexpected inflows (-2) & 8.05 & 3.77 & 2.16 & 0.04 \\
\hline Unexpected inflows (-3) & 3.54 & 3.75 & 0.94 & 0.35 \\
\hline
\end{tabular}

the regression should be made on expectation revisions about the evolution of the investor base. As expectational revisions are not directly observable auto regression model is used. Using Schwarz and Akaike criteria that can help to evaluate best fit of the model, the best model was chosen or the model AR(3), shown in Table 6. We use the residuals for the series of the expected (adjusted) foreign inflows. Unexpected net inflows will be defined as observed inflows minus investors' expected net inflows.

\subsection{Results: Price pressure hypothesis}

Findings proved that foreign trading impacts contemporaneously the returns on the Macedonian stocks. It is very important if this effect is only temporary so that price movements impacted by foreign inflows are not permanent but are caused due to lack of liquidity of local markets, being reversed on the following months. If this is case then foreign trading can be harmful due to generation of more volatility to the local financial markets. To find out if the impact is permanent or temporary price pressure hypothesis regression from equation (2) was used and results are presented in Table 7.

There is positive and significant coefficient calculated for the lagged unexpected inflows for two months. The explanation of the coefficient will be that unexpected inflows two months behind will produce 8.05 percentage increases in the monthly returns. Rejection of the null hypothesis gives evidence that there is no price pressure and can be concluded that there is permanent increase in the prices.

\section{CONCLUSION}

The paper addresses the influence of the foreign capital inflows on the stock prices at the Macedonian capital market. It was general belief among the participants on the Macedonian Stock Exchange that foreign investors are the reason for the boom, but as well for the recession on the Macedonian Stock Market. The analysis of the impact of foreign inflows on the stock prices confirmed the general belief among market participants that foreign flows at the Macedonian capital market have a significant impact on stock prices. There is evidence that the base of investors is broadened, and the results showed that $1 \%$ of monthly net inflows as a percentage of last month market capitalization is connected with $7 \%$ rise in monthly returns on the Macedonian stock market. The research coincide with the researches already done (Clark and Berko 1996; Dahlquist and Robertson 2008; Richards 2005; İkizlerli and Ülkü 2008).

Price pressure hypothesis was employed to find out if this increase in stock prices is temporary or permanent. Price pressure due to foreign inflows is not found; the rise in the prices is permanent. The results showed that unexpected inflows two months behind will produce 8.05 percentage increases in the monthly returns.

The policy makers, practitioners, investors, fund and portfolio managers should benefit from the findings of this research. It gives quantification of the impact of foreign capital inflows on the prices of the securities at the Macedonian Stock Exchange and shows that foreign investors push the increases in prices and it is permanent. Even though the results are in line with previous researches in emerging markets, still the limitation of the study is that it is made only at the Macedonian stock market. Further researches should be focused on other Balkan stock markets to confirm the findings.

\section{REFERENCES}

Angelidis, D., Koulakiotis, A., and Kiohos, A. 2018. Feedback trading strategies: the case of Greece and Cyprus. The South East European Journal of Economics and Business 13 (1):93-99. http://journal.efsa.unsa.ba/ index.php/see/article/view/744.

Angelovska, J. 2014. Month Related Seasonality on the Macedonian Stock Market. Business and 
Economics Research Journal 5(1):143-150.

Bekaert, G., and Harvey, C. R. 2002. Research in Emerging Markets Finance: Looking to the Future. Working paper, September 11.

Bekaert, G., and Harvey, C. R.. 2000. Foreign Speculators and Emerging Equity Markets. Journal of Finance 55: 565-613.

Bekaert, G, Harvey, C. R. and Lumsdaine,R. 2002. The Dynamics of Emerging Market Equity Flows, Journal of International Money and Finance 21: 295-350.

Bohn, H., and Tesar, L. L.. 1996. U. S. equity investment in foreign markets: portfolio rebalancing or return chasing? American Economic Review 86:77-81.

Brennan, M. J., and Cao, H. H., 1997. International portfolio investment flows. Journal of Finance. 52:1851-1880.

Choe, H., Bong-Chan Kho, and Stulz, R. M. 1999. Do foreign investors destabilize stock markets? The Korean experience in 1997. Journal of Financial Economics 54:227-264.

Clark, J., and Berko. E. 1996. Foreign Investment Fluctuations and Emerging Market Stock Returns: The Case of Mexico. Research Paper from Federal Reserve Bank of New York, Number 9635.

Dahlquist, M., and Robertsson, G. G. 2004. A note on foreigners trading and price effects across firms. Journal of Banking \& Finance 28: 615-632.

Errunza, V., Senbet, L., and Hogan, K. 1989. Capital flow controls, international asset pricing, and investors' welfare: A multi-country framework. Journal of Finance 44: 1025-1037.

Froot, K., and Ramadorai, T. 2001. The information content of international portfolio flows, NBER Working Paper No. 8472.

Griffin, J. M., Nardari, F., and Stulz, R M. 2004. Are daily cross-border equity flows pushed or pulled? The Review of Economics and Statistics 86(3):641-657.

Grossman, S.1995. Dynamic asset allocation and the informational efficiency of markets. Journal of Finance 50: 773-788.

Grossman, S., and Stiglitz, J. 1980. On the Impossibility of Informationally Efficient Markets. American Economic Review 70: 393-408.
Henry, P. B. 2000. Stock Market Liberalization, Economic Reform, and Emerging Market Equity Prices. Journal of Finance 55: 529-564.

İkizlerli, D., and Ülkü, N. 2008. Foreigners Trading and Returns in Istanbul Stock Exchange. Istanbul Stock Exchange Review 5 (17): 93-124.

Kim, H. E., and Singal, V. 2000. Stock Market Openings: Experience of Emerging Economies. Journal of Business 73: 25-66.

Lin, M-C., and Ma, L-C. 2002. The interactions $\mathrm{s}$ between institutional trading information and market returns. Review of Securities and Futures Markets 14:113-143.

Merton, R. C. 1987. A Simple model of capital market equilibrium with incomplete information. Journal of Finance 42: 483-510.

Pavabutr, P., and Yan, H. 2007. The Impact of Foreign Portfolio Flows on Emerging Market Volatility: Evidence from Thailand. Australian Journal of Management 32(2):345-368. DOI: 10.1177/031289620703200209

Richards, A. 2005. Big Fish in Small Ponds: The Trading Behavior and Price Impact of Foreign Investors in Asian Emerging Equity Markets. Journal of Financial and Quantitative Analysis 40: 1-27

Stulz, R. M. 1997. International portfolio flows and security returns, Unpublished working paper. Ohio State University, Columbus, $\mathrm{OH}$.

Tabak, B. M. 2003. The Random Walk Hypothesis and the Behavior of Foreign Capital Portfolio Flows: the Brazilian Stock Market Case. Applied Financial Economics 13.

Tesar, L., and Werner, I. M.. 1995b. U.S. equity investment in emerging stock market. World Bank Economic Review 9:109-130.

Tesar, L., and Werner, I. M. 1995a. Home bias and high turnover. Journal of International Money and Finance 14:467-492.

Warther, V. A. 1995. Aggregate Mutual Fund Flows and Security Returns. Journal of Financial Economics 39: 209-235.

Yu, C. H., and Yung, C. Lai. 1999. On the informational leading role of foreign institutional investors. Journal of Financial Studies 7:1-26. 